\title{
Obturator Lymph Node
}

National Cancer Institute

\section{Source}

National Cancer Institute. Obturator Lymph Node. NCI Thesaurus. Code C88141.

A pelvic lymph node located along the obturator artery. 